\title{
A postmodern Post-feminism without Women
}

\author{
Alison Assiter*, María J. Binetti* \\ *Correspondence: alison.assiter@uwe.ac.uk; mjbinetti@gmail.com
}

Peer review: This article has been subject to a double blind peer review process

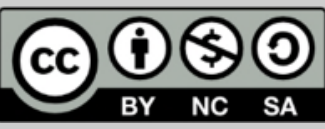

C Copyright: The Authors. This article is issued under the terms of the Creative Commons Attribution NonCommercial Share Alike License, which permits use and redistribution of the work provided that the original author and source are credited, the work is not used for commercial purposes and that any derivative works are made available under the same license terms.

\section{Abstract}

This article aims at showing the way in which the discursive constructivism and ethical relativism characteristic of postmodern feminism and postfeminism leads to a neo-liberal and conservative political agenda that threatens women's sex-based rights. The article will especially focus on the thought of Paul-B Preciado as a post-feminist activist. It draws a comparison also with the work of Saba Mahmood. In such a context, we will point out the necessity of a neo-material and realist framework able to account for the ontological reality of women, and their irreducibility to social hetero-norms.

Keywords: Constructivism, nominalism, embodiment, sexual difference, human rights, materialism.

\section{Introduction}

This paper is an intervention in the debate about postmodern post feminisms in the light of new materialism. It engages critically with the work of Butler and that of Paul Preciado and seeks to show some of the political consequences of the work of the latter. We argue that some of these are neo-liberal and conservative. ${ }^{1}$

The paper defends a dynamic conception of the biological against those who reduce the latter to an inert essence. It sets out to show how the 'performative' conception of the body, articulated by the brilliant theorist, Judith Butler, has led, on the one hand, to a version of queer theory, in the work of Preciado, where 'anything goes' including forms of sexual practice that hark back to de Sade. Of course, there are a myriad effects of the work 
of Butler some of which have had positive political consequences. But another influential follower of Butler is Saba Mahmood who has critiqued human rights and claimed that they are 'western' constructions. This paper deals mainly with the work of Preciado and sets out to show the trajectory from Butler to Preciado. Our article focuses on Preciado's work, rather than that of other queer theorists, as we believe that their work is particularly compelling. But it also mentions the parallel move, from the work of Butler to that of Mahmood and suggests links between these two progenitors of Butler's work. Both Preciado and Mahmood end up, we suggest, in positions that are conservative and neo-liberal. We make no claim, of course, that Butler would agree with positions taken by those who have been profoundly influenced by her work.

What is presented, in Preciado's work, as a dissection of the 'heteronormative and colonial epistemology of the body' (Preciado, 2018, 5) moves, we believe, into something politically altogether more disturbing. We will also argue that although there are contexts where binaries deserve criticism, the proposal that the binary man/woman is a creation of western colonial capitalism is politically damaging and dangerous. It connects with the denial of universals and with the critique of human rights in the work of Mahmood. This is a paper that is partly philosophical. But it is a philosophical paper with political effects.

Postmodern feminisms occurred in part as a result of the linguistic turn in philosophy in the twentieth century. The latter was a major development in philosophy whereby key philosophical problems were to be resolved by focusing on the meaning of expressions. So, for example, a concept like 'responsibility' or 'class' was to be analysed by focusing on the way 'we' use these expressions. Many concepts, therefore, in this way of thinking, can be reduced to socio-linguistic constructions performed by speaking subjects. In her book Enlightened Women, Assiter (Assiter, 1996) made a connection between this philosophical perspective and Humean 
skepticism, where no connection can be made between an 'idea' or a concept and a real body. Real bodies effectively cease to exist since their existence can never be known with certainty.

Post modernism, then, in a certain vein, lies in this broad trajectory. For one of the most famous of the thinkers broadly associated with this position, Judith Butler, the idea that there is a 'subject', woman, is wrong headed. Instead the category 'woman' is a construct produced by the very system that is supposed to facilitate its emancipation. There is no woman who initiates feminist goals. Rather 'woman' is a production; she is effectively a fiction. Butler critiques feminists use of the category 'woman' as falsely essentialising a notion that is historically and culturally formed, and that, indeed, skates over significant differences amongst women. Butler is, of course, not by any means the only person to have argued this but, as we will demonstrate, there is a very big difference between accepting that there are many categories of woman and suggesting that the very concept of 'woman' is a fiction. Moreover her thesis, as Karen Barad (Barad, 2003) has pointed out, is not the simple claim that speaking subjects construct the self. It is rather a more subtle view to the effect that there are 'unexamined' habits of mind that give language power in constructing the self.

We begin the article, then, with what see as a crucial aspect of Butler's writing that leads to a certain version of queer theory. This is Butler's discussion of what would now be termed 'abject bodies'.

\section{Butler on Abject Bodies}

For Butler, in Bodies that Matter, (Butler, 1993) 'performativity' is equated with the power of discourse to produce bodies. Instead of being born women we are rather constructed as women. Norms of gender work on bodies to create woman in a hetero-normative fashion. In a recent twist in 
this story, post-modernism, in a certain vein, has become post-feminism where women are nothing but the old-fashioned constructions of heteronormative regimes. Preciado's work draws on that of Butler but moves in an entirely new direction. We believe that their work, as noted, although it draws on other queer theorists and philosophers, is particularly significant.

Sex, then, as well as gender, for Butler and others, is a construction, defined as the set of effects-namely, representations, behaviors, desires, social relations, etc. produced in bodies by the deployment of complex political technologies (de Lauretis, 1987, 3). Prior to this, the theory of gender was articulated within the so-called 'sex/gender system' (Gayle Rubin, 1975,159$)$ and was interpreted as the political economy of material bodies. This sex-gender system reproduced the classic -phallogocentricdualism between a merely passive, indeterminate and receptive material substratum, and an active, determinant and generating form, attributed in some cases to the socio-linguistic performativity of rational and speaking subjects (Gatens, 1996).

The hylomorphism involved in versions of the sex/gender system installed a dualist opposition and radical discontinuity between material bodies and speaking subjects, nature and culture, human and non-human beings. This kind of dualism is conceptually fragile, unstable, and tends under its own weight to a monist reductionism, as shown by feminist queer theory. Judith Butler took the decisive step in that direction overcoming the sex/gender dualism by a linguistic monism - the denial of a duality between discursive construction and material bodies - performed by socio-discursive agents.

Butler is skeptical of the Enlightenment subject; of foundationalism; of mind/body dualism; of substance metaphysics and of the dualism that goes along with that between mind and body, between freedom and 
determinism. We concur with her critique of these positions but dissent from her conclusion. The conclusion she draws from her critique is a Foucauldian inspired one-namely that there is no 'identity' of woman; there is no universal human. Rather, the body itself and the self are 'performatively enacted significations' (Butler, 1990, 33). For her, following Foucault, the "body is not "sexed" in any significant sense prior to its determination within a discourse through which it becomes invested with an «idea» of natural or essential sex' (Butler, 1990, 92) 'Sexuality is an historically specific organization of power, discourse, bodies and affectivity' (Butler, 1990, 192). What Butler calls the 'maternal libidinal economy' is, following Foucault's approach, an effect of discursively constructed power relations. The 'maternal body' is discursively produced but constituted as natural and 'pre-discursive' (Butler, 1990, 92).

In this way, sex-gender dualism is replaced by a version of nominalism beyond whose discursive practices there is nothing. Bodies, sexes, sexualities, libidinal economy, affects, desires, maternal attachment all turn out to be the historical and contingent outcomes of powerrelationships. They are not materially formed, but rather they are sociolinguistically materialized in and by discursive practices. That means that physical materiality, bodies, desire, sexes and sexualities are language's coagulations - purely the flatus of their discourses.

Language performs the real, normalizes some identities and marginalizes others. One of the classic arguments used by Butler to show how language normalizes reality is focused on the so-called abject bodies, kept out of the norm. In Gender Trouble, Butler recovers the story of Herculine Barbin and discusses Foucault's engagement with the case in his work The History of Sexuality. Herculine was a nineteenth century French 'hermaphrodite' (she was so labelled by both Foucault and Butler). 'She' was assigned the sex of female at birth. In her twenties she was legally forced to alter her sex to that of male. Butler is sympathetic to the overall approach taken by 
Foucault, in his claim to the effect that the sexed body is 'produced' by discursive practices in the context of power relations. Following him, she reads sex and sexuality as historically specific organizations of power relations.

However, she thinks that Foucault does not understand Herculine and he contradicts his own theoretical framework in his discussion of the 'hermaphrodite'. She criticizes Foucault for romanticizing Herculine in a world of 'pleasures as the 'happy limbo of non-identity', a domain that exceeds the categories of sex and of identity' (Butler, 1990, 94). Foucault, Butler argues, 'takes a stand' (Butler, 1990, 95) against some liberatory models of sexuality because they don't acknowledge the historical production of sex as a category. Some previous feminist analysis, according to Butler's reading of Foucault on this subject, takes sex as its point of departure whereas he wants to outline the way in which sexual difference is 'constructed' within discourse. According to Foucault, if, therefore, 'sex' disappears, then there is a happy world of bodily pleasures outside the binary construction of most sexed bodies. Herculine, according to Foucault, depicts a world of a primary sexual multiplicity analogous to the 'primary polymorphousness' of psychoanalysis or the 'original and creative bisexual Eros' of Marcuse.

In her challenge to this picture, Butler argues that Foucault has failed properly to understand Herculine. The latter's journals narrate his/her unhappy, tragic life of 'unjust victimization, deceit, longing, and inevitable dissatisfaction' that culminates in her/his suicide. Butler chooses to read Herculine very differently from Foucault. She asks the Foucaultian question: 'what social practices produce sexuality in this form?' Herculine is 'produced', in Butler's reading, 'by romantic and sentimental narratives of impossible loves'. It is especially difficult, according to Butler, to separate 'gender' from 'sex' in Herculine's case. Herculine's confusions and unhappiness point to their unsettling of binary categories. Herculine's 
'laughter' or is it Foucault's laughter following a reading of Borges shattering of the Aristotelian distinction between universals and particulars, designates 'humiliation or scorn' (Butler, 1990, 104). For Butler, Herculine's sexuality is both produced by the law and outside the law. 'She' 'embodies the law, not as an entitled subject, but as an enacted testimony to the law's uncanny capacity to produce only those rebellions that it can guarantee will - out of fidelity - defeat themselves and those subjects who, utterly subjected, have no choice but to reiterate the law of their genesis' (Butler, 1990,106). In other words, Herculine is constructed by the law in such a way that she always remains outside its sphere of jurisdiction.

Summing up, the case of inter sex people-labelled by Butler and Foucault 'hermaphrodites'- serves to illustrate the constructive and normative character of sexual difference, that is, the political construction of women along with the fictional construction of feminism. According to Butler, 'woman' is a normative category used for including and excluding, rewarding and punishing. Men and women exist as social norms, political signifiers of a hetero-normative regime that it is urgent to remove.

Butler claims that there is no universal women partly because some women would dissent from being thus labelled, i.e., according to her, labeled as the dominated class of a hetero-normative regime (Butler, $1990,3)$. She dissents from what she calls 'fictive' forms of universality or the false claims of some universalisms that disguise westo-centric assumptions about women. She is also critical of foundationalism and she implies that the 'liberal' universalizing project rests on false foundationalist premises.

Butler's radical socio-linguisticism marks the passage from feminist philosophy to post-feminist queer studies, focused on abject bodies released from all heteronormativity and, then, constructed beyond sexual 
difference as free materializations. Queer multitudes are the very vanguard: the true advanced performers in counter-sexual and counterreproductive matters.

\section{Preciado}

Paul Preciado is brilliant writer, philosopher, curator and an influential thinker. In an interview conducted when Paul wrote as Beatriz Preciado, Ricky Tucker writes: Beatriz 'toggles between a personal account of using topical testosterone, Testogel, as a kind of performative homage to a fallen queer friend, and a cultural analysis that investigates how pharmaceutical companies politicize the body- down to the molecule (Tucker, 2013). Earlier, Tucker had been desperately trying to worm his way into a packed lecture theatre where Beatriz was speaking about their then new text Testo Junkie.

Preciado, as noted, challenges the existence of 'binaries' and argues that binary thinking is an effect of western colonial capitalism. Quoting them: 'The homosexual identity, for example, is a systematic accident produced by the heterosexual machinery; in the interest of the stability of natureproducing practices, it is stigmatized as unnatural, abnormal, and abject' (Preciado, 2018, 28). This 'bourgeois, colonial, central European genitalprosthetic machinery' stigmatises abject bodies. Among all of these bodies therefore, woman and man 'are reduced to two elements with equal status as Butch or Drag King' (Žižek, 2017, 135), that is, woman and man are registered like so many other cultural constructs but, unlike the others, they are basically determined by hetero-norms. The normative discourses construct our sexuality, our gender and our sex. Preciado's own taking of testosterone is not merely an act designed for themselves. It is, for them, a political act. Preciado takes it to 'foil' what society wanted of them. 
For Preciado, the various creations of the pharmaco/pornographic discourse, the 'queer multitudes', are enriched by the prosthetic, hormonal, cybernetic, pharmarco- and neuro-devices of postindustrial capitalism available for discovering new transgender experiences. Prosthetic bodies injected with silicones, hormonally controlled, surgically amputated, and inspired by sophisticated technologies of pleasure relying on dildos, anal practices, fist-fuckings, sadomasochism, intoxications and many other possibilities of queer invention open for us the way to countersexuality (Preciado, 2018). 'The cyber-teratological social imaginary of late postmodernity' (Braidotti, 2002, 170), invite us to perform the emptiness of the real by a pharmaco-pornographic reason of counter-sexual character. Preciado themselves claims to want to 'feel a form of pleasure that is post pornographic' (Preciado, 2013, 1).

On the stage of a radical post-feminism come forward the 'multitudes queer' (Preciado, 2003), potentially infinite, undecidable and in permanent construction. In Testo Junkie, Preciado's bodies become the effects of the pharmaceutical and the pornography industries. In this text, Preciado demonstrates how hormones have affected the way in which gender and sexual identity are formulated, and how the pharmaceutical and pornography industries serve to create desire. It includes a dramatic account, as noted, of Preciado's use of testosterone each day for a year and its effect on their desires as well as their imagination and writings. What we have, in Foucauldian vein is the 'biomolecular (pharmaco) and semiotic- technical (pornographic) government of sexual subjectivity' (Preciado, 2013). To quote Preciado once more: 'The psychoanalytic notion of castration depends on a heteronormative and colonial epistemology of the body, a binary anatomical cartography in which there are only two bodies and two sexes: the masculine body and subjectivity, defined in relation to the penis, a (more or less) extruded genital organ, and the female body and subjectivity, defined by the absence of a penis' (Preciado, 2018, 5). Although the intention is no doubt different, is 
Preciado here smuggling in a defence of castration? One of Preciado's talks was called Hacking the Binary² so does the word 'hacking' have more than metaphorical significance?

More likely, though, is it that, for Preciado, discursive practices are the non plus ultra of a nominal reality. Such a scenario recreates the long history of nominalism - the idea that universal concepts are merely names without any reality - in the form of a radical trans-constructivism, philosophically resolved in skepticism, relativism and nihilism, and politically effectively annihilating many forms of critique of the status quo. $^{3}$ Nominalists effectively deny the existence of universal kinds and see only a proliferation of particulars. Obviously, the use of testosterone affected Preciado's hormone balance and therefore their biology. However, this, like the use of a dildo, is, for them, a choice. It is possible, Preciado argues, governed, in part, by the pharmaco-pornography industries, to choose one's sex, one's gender alongside other aspects of one's personality. We have therefore a proliferation of particular types of sexuality and no general categories like men or women. Being a man or a woman is also a choice.

Categories such as gender, trans genders, cross dressers and queerness and many more dominate Preciado's post-feminist scene. There is of course nothing wrong with celebrating both some aberrant forms of sexuality and 'abject bodies'. Indeed it is politically important to celebrate 'deviant' bodies of many kinds in a capitalist world that discriminates against the 'abnormal'. One of our worries, though, reflects a point made some time ago about Butler's work. Some time ago Martha Nussbaum argued of the work of Butler and related theorists, that: 'It is the virtually complete turning from the material side of life, toward a type of verbal and symbolic politics that makes only the flimsiest of connections with the real situation of real women. Feminist thinkers of the new symbolic type would appear to believe that the way to do feminist politics is to use words 
in a subversive way, in academic publications of lofty obscurity and disdainful abstractness. The new feminism, moreover, instructs its members that there is little room for large-scale social change, and maybe no room at all. We are all, more or less, prisoners of the structures of power that have defined our identity as women; we can never change those structures in a large-scale way, and we can never escape from them' (Nussbaum, 1999). Nussbaum also wrote, in the same piece: 'In India, for example, academic feminists have thrown themselves into practical struggles, and feminist theorizing is closely tethered to practical commitments such as female literacy, the reform of unequal land laws, changes in rape law (which, in India today, has most of the flaws that the first generation of American feminists targeted). In other words, according to Nussbaum, these academic feminists are activists in important feminist campaigns.

Our - Assiter and Binetti's - point is not that it is wrong to write theory. Our concern is rather about a particular type of theory that challenges the existence of real embodied women, who, as embodied women are, for example, victims of rape and unequal land laws. As another writer put it: 'Where did we ever get the idea that nature - as opposed to culture - is ahistorical and timeless' (Shaviro, 1997).

We might ask the question of Preciado: why is it that it is seen to be specifically 'colonial' capitalism that is said to create the binary man/woman? It is important to note that it is not merely characters who experiment with their sexual desire, like Preciado and other recent western queer theorists, who are said to challenge the binary man/woman. For example, in some Native American cultures it is seen as discriminatory to ask a Two Spirit person (who can be a man or a woman) to perform the gender role of male or female. ${ }^{4}$ The Ojiwbe language describes such people who can be men or women. We-Assiter and Binetti - appreciate that there has been and still is significant and disturbing 
discrimination by western colonial powers against these such people as well as against trans persons in contemporary western cultures. Indeed, a 16 year old Navaho was the victim of a hate crime, killed for being a 'two spirit' or (pejoratively) an 'effeminate male'. ${ }^{5}$ But the step from this to the assumption that it is western, colonial capitalism that has 'created' the binary of sex seems to us to be a step too far. There are sexed beings amongst animals and there is a real risk, if human sex differences are seen to be brought into being by ideological forces stemming from western capitalism, that a new form of what we see as a destructive binary between animal and human - is created. According to Preciado and others, human sexual difference is created by colonial capitalism. Animal sexual difference is outside this. This view, however, challenges the continuity that we need to assume, between human animals and other animals in order to accord the natural world the value that it deserves and requires in the contemporary context. It seems moreover, that it may be the case, as Gita Sahgal has suggested, that the idea of transgender is a modern western construct which has been applied to Two Spirit people and many other pre-colonial gender fluid people/ subcultures. Indeed, according to de Vries (de Vries, 2009) the term was adopted at a conference in 1990 at an indigenous lesbian and gay gathering in Winnipeg. If it were not for the imposition of western categories on native people, why would the very binary - man/woman or male animal/female animal - be seen to be a construction of colonial capitalism? It is a huge step from appreciating and condemning the discrimination against Navaho peoples to suggesting that two spirit people challenged the very existence of men and women.

It is worth mentioning another body of work at this point that may suggest that biological sex is connected to western, Eurocentric normative assumptions. This is, to mention only one of a number of important works, the book The Invention of Women: Making an African Sense of Western Gender Discourses, by Oyeronke Oyewuma. ${ }^{6}$ Oyewuma argues that the view that sex and gender are universal organising categories is a western 
normative assumption effectively imposed upon all African cultures. She suggests that this assumption is founded upon western dualist distinctions between mind and body (with body associated with irrationality and with women). In turn, these western assumptions rest upon visual cultures. In the Oyo-Yoruba lived experience in western Nigeria, by contrast, she argues, other senses are used. The dominant organising principle of everyday life is 'seniority' - seniority within the family. 'Outsiders' occupy less senior roles. Gender and sex, by contrast, are not significant organising principles. One of her arguments in support of the latter view is that there are no words for 'man' and 'woman' in the Yoruba language but only words for 'female' and 'male'. Anatomy, therefore, she argues, plays no role in position or status in Yoruba language and culture.

We would like to make three brief points in response to this. Firstly, we entirely concur with Oyewuma's critique of the western binary mind/body and with her critique of the dominance of vision in certain versions of western philosophy. However, ironically, it is feminists in the west who have been amongst the primary critics of these assumptions. Our own work which focuses on a dynamic materiality, in continuity with the animal world, challenges the form of dualism Oyewuma critiques. But we believe, with Bibi Bakare-Yusuf, however, that Oyewuma perhaps over-estimates the power of language in social, cultural and, indeed, biological realities. Bakare-Yusuf argues that, in her view, the power dynamics in Yoruba social realities are more fluid and there are more of them, than is suggested by the picture painted by Oyewuma. To offer a counter-example of our own to Oyewuma, there are no gendered pronouns in Farsi but I have yet to meet a first language Farsi speaker who would claim that this indicates a lack of gendered power relations in Iranian culture. Moreover, one important point, for us here, is that Oyewuma does not deny the existence of males and females and she therefore is making a different claim from that of Preciado. Accepting her view about Oyo-Yoruba cultural assumptions and lived reality, therefore, indeed suggests that gender is 
less significant as a normative organising principle than it is in many parts of the world. However, this does not lead to the view that biological sex is a construction of western colonial capitalism. We suggest that Oyewuma's work has some features in common with the tradition of Foucault and Butler in her emphasis on the power of language in shaping cultural realities but she does not go so far as Preciado.

Preciado is continuing the tradition of Foucault and Butler, then, in their histories of the various modes of normative construction of bodies. Like them, Preciado is offering an analysis and critique of these modes of normative construction. However, like them, he is complicit in creating a mode of discursive analysis that 'essentialises' in a reductive fashion and effectively therefore denies, the biological body and its rights. It is important to note that while there are many LGBTQ victims of domestic violence, it is still the case that the vast majority of perpetrators are men (see Romans et.al, 2000). Women experience higher rates of repeated victimisation and are much more likely to be seriously hurt or killed than men (see Walby and Towers, 2017, also Walby and Allen, 2004). Moreover if Preciado's view were adopted, the UN definition, which is vital for protecting all women, would no longer make sense. The UN defines gender based violence as 'violence directed towards a woman because she is a woman' (CEDAW, 1992, para 6. See also Hague, 2021) ${ }^{7}$ Less seriously but still importantly, Preciado's position may lead to the denial, for example, of the rights of women in the following groups: a recent survey conducted for a group in Spain found that $80 \%$ of the 12,600 women who responded were struggling to balance teleworking with childcare. In Valencia a study showed that mothers were the ones 'ensuring children kept up with online classes and homework during the lockdown' (Connolly, Kate and Kassam, 2020). These women's rights cannot be articulated as women's rights, on Preciado's analysis, since the category 'woman' is said to be a hetero-normative construction. Moreover, if men and women are 
purely creations of these discourses and industries how can they act to change these and other practices?

\section{Counter-sexual Trans-fictions}

Paul Beatriz Preciado, then, draws from Butler's abject and abnormal bodies the measure of a fictional reality. Drag kings, men without penises, wherewolves, butch women, handi-cyborgs, and so on (Preciado, 2003, 23) become the new criteria for a fictional techno-constructive order, which takes revenge against the old regimes of normalization. They declare the reality of all self-perception, desire and discourse. Selflabelling is not merely a psychic expression but becomes the person in her reality. A person who self-defines as trans or queer or bi, by virtue of that self-definition takes on that form. Preciado and those who follow such a stance, take revenge against any theory that supports the ontological status of sexual difference. Rather they replace it with pharmaco-technosexualities on demand.

To quote from Preciado's Counter-sexual Manifesto: 'The elaborations on queer theory carried out by Judith Butler and Eve Kosofsky Sedgwick in the 1990s have made it clear that the apparently descriptive expressions 'it's a girl' and 'it's a boy,' spoken at the moment of birth (or even at the moment the fetus is visualized via ultrasound), are in fact performative invocations, closer to the contractual expressions spoken in social rituals, such as the 'I do' of marriage, than to descriptive statements such as 'this body has two legs, two arms, and a tail' (Preciado, 2018, 27). Instead the body is a 'living, constructed text'. (Preciado, 2018, 25). It is indeed, an interesting point that, in the contemporary activist debates 'cis' women are defined as those who were labelled female at birth. Is it not a possibility, then, that the vary act that is used, in these debates, to define 'biological' women may itself be a fictional construction? Instead of being born a male, as with a male monkey, it is the act of naming 'it's a boy' that 
defines who counts as a male or female on this way of thinking. But what then counts as defining which one is a female or a male monkey? Is there a parallel act of naming for them?

The fictional universe of Preciado rests on the first principle of the «dildo» as the de-ontologizing imperative of everything. It says: 'in the beginning was the dildo. The dildo preceded the penis. It is the origin of the penis' (Preciado, 2018, 22). The universal dildonization discovers the caricature of the origin by a sort of trans-masculine performance of phallocentrism. And given that from the dildo nothing comes out, all becoming is real. Preciado's dildos offer a long line-up of postmodern narratives about simulacrums without original or copy, fables without morals, and signifiers without signified. Hence, in tune with the post- metaphysical and posthistorical parody, Preciado states the dildonization of everything. Given, therefore, that the penis is erased, does the drag queen then not become the 'real' woman?

The conditio sine qua non for queer policies is the 'de-ontologization of the subject of identity's politics: there is no more natural base (woman, gay, etc.) that can legitimize the political action' (Preciado, 2003, 24). By 'natural' Preciado understands - just like Butler - a given and immediate substrate that pre-exists and determinates the cultural world according to eternal designs. By contrast, Preciado offers the political action of deontologized subjects of enunciation. Speaking subjects perform whatever counter-sexuality they want. They can perform as intersex bodies, transgender and transsexual bodies, queens, diesel dykes, faggots, butches, the hysterical, the horny and the frigid, the sexually disabled and the mentally ill, hermaphrodykes, etc'. Indeed, they can perform in whatever manner they wish, to 'bolster the power of deviating and drifting from the heterocentric biowriting machine' (Preciado, 2018). 
According to Preciado, 'bodies recognize themselves and others not as men or women but as living bodies. They recognize in themselves the possibility of gaining access to every signifying practices as well as every position of enunciation' (Preciado, 2018, 20). In the constructivist framework of postmodernity, to live is to speak.

The first article of the Counter-sexual Manifesto demands that we erase the sexual codes of masculinity and femininity and turn them into 'open and copyleft registers available to speaking, living bodies within the framework of mutually agreed-upon impermanent contracts' (Preciado, $2018,32)$. The categories of male and female, in this world, become currencies of exchange in the free market of culture. They become political signifiers available to somatic fictions or somatechnics of free choice. All unborn people, all babies and children must be preserved from a sexual ascription which forces them into a hetero-normative system. Instead, they must be ensured the right to a sexed-free birthing, an indeterminate body, to asexual registers, a gender-free upbringing, and the use of the neutral pronoun «elle» or 'they' (used in the English language as a singular form). 'The body's countersexual resignification shall become operational with the gradual introduction of certain countersexual policies. First, practices stigmatized as abject within the frame- work of heterocentrism shall be universalized. Second, high-tech countersexual research squads shall be created so that new forms of feeling and affection can be subjected to collective experimentation' (Preciado, 2018, 33).

Queer subjects are neutral parlêtre who perform their own countersexualities according to self-referential perceptions, imaginaries, desires and with the help of pharmaco- or cybertechnologies of high complexity and sophistication. These counter-sexualities are 'products, instruments, apparatuses, gimmicks, prostheses, networks, applications, programs, connections, fluxes of energies and information, circuits and circuit breakers, switches, traffic laws, borders, constraints, designs, logics, hard 
drives, formats, accidents, detritus, mechanisms, usages, and detours' (Preciado, 2018, 21). The construction of such artifacts is a hard task that consumes large amounts of linguistic energies. The difference between this sort of sexual homo faber and the classic androcentric subject consists in the naive constructivism of the former compared with the naive realism of the latter, both unilaterally built on a reason either instrumental or contemplative.

Counter-sexualities, on this view, are the techno-constructions of a discursive and instrumental reason empowered by bio-capitalism. All this has little to do with what Sigmund Freud has called sexuality and psychoanalysis. To judge by the techno-sexual practices described by Preciado, namely: sadomasochism, fetishism, fist-fucking, counterpornography, dildotectonics, surgeries, flows of hormones, silicone and so on, then counter-sexuality would be close to what Freud calls the 'death drive' or Todestrieb, and is opposed to the sexual drive or Sexualtrieb. In fact, counter-sexual drives, in Preciado's thought, reveal a will to power, a control and disciplining of bodies rather than eros and vital energy. In Preciado's own terms, counter-sexuality is a 'politics about death, without any vitalistic populism', a 'cultural necrophilia' that leads us to 'via mortis' (Preciado, 2013, 417-18). What does this mean, then, for reproduction?

Counter-sexual drives take us back to Foucault and, along with Foucault, to the Marquis of Sade. In his Lectures on Sade, Foucault (Foucault, 2015, 93-146; Raymond, 2001, $43 \mathrm{ff}$.) reveals to us the quintessence of queer counter-sexuality, i.e., cruelty, evil, crime, disorder, and libertinage. This is de Sade, the queer referent of a desire released from all social norm, transcendent ideal or immanent measure, and surrendered to the arbitrariness of self-perceptions and self-referent signifiers. Just like queer multitudes, Sade's libertines are micro-politicians for whom 'there is no general system of libertinage, but for each libertine there is a system, and those systems define the singularity' (Foucault, 2015, 139-40). 
It is no accident that Preciado begins the Counter-Sexual Manifesto with a discussion of de Sade. De Sade, he writes, wrote the 120 Days of Sodom while in prison and hid the manuscript in a dildo. Both for Foucault and Preciado, 'Freudian discourse and Sadean discourse are strictly incompatible' (Foucault, 2015,144). But it seems that this is, in Preciado's work, to the detriment of Freud and the advantage of de Sade. Moreover, to the extent that both are just fictional discourses, there is no criterion, neither transcendent nor immanent, of truth. There is merely the invention of discursive practices in constant counter-normativity. No matter if Sade leads us to the torture and rape of women, to sexual or reproductive exploitation, to pederasty or female brutalization. The important thing is the abnormality, the transgression and the resistance to the norm under the premise of the performative parlêtre in a disciplinary society.

In the Foreward to the Counter-Sexual Manifesto, we read... 'it is epistemological warfare in which the butch must be recognized not as an anachronism, a failed copy, a sad imitation of men, but as part of a new postwar industrial landscape in which soldiers, housewives, and Hollywood actors all deploy prosthetics to try to cover up the shattered land- scape of the natural world' (Preciado, 2018, x).

Even if the linguistic nominalism does not lead quite to de Sade, the difficulty is that there is no independent norm against which to judge which practices are abhorrent, which run counter to any form of feminism or which are merely odd. Accepting that a trans man is a man and therefore a father giving birth, is one thing. But accepting the different point that a sex offender can gain access to a woman's prison or an athlete can get access to a sport where 'she' has an unfair advantage of a male body, to take two examples, is different. 
The very least that this perspective leads us to, then, is a form of absurdity where any clothes fit any person but also to a form of dictatorship where no-one else is able to deny that they fit for fear of hurting the feelings of the person concerned. More strongly, any abusive language is allowable from someone who wishes to challenge the self-referential perceived sex of the person concerned.

\section{The Downfall of any universal Institution}

The queer multitudes, with their socio-linguistic origin and becoming, like Mahmood and her followers, reject any concept of universality ontological, political or scientific- and adjust their politics to individual decisions and particular contexts. They interpret the universal as the representative abstraction of some common socio-linguistic features, with the conclusion that there are no 'essential' or 'universal' characteristics of humanity, and therefore no universal claims for democracy, republican institutions, human rights, animal rights, scientific knowledge and so on. The claim for any of these institutions would be, for them, inspired by the foundational narrative on some transcendent and eternal essences, that are supposed to direct the progress of universal history to a happy and perfect end. There could be no sex rights, no rights of women not to wear a hijab, no universal human rights of any kind at all.

The end result in this universe of mere flatus vocis is, however, the ontological liquidation of woman's identity, the setting of a post-feminism performed by transvestites and MTF, and the dissemination of an undecidable form of socio-linguisticism that eliminates the possibility of any universalist perspective. It capitulates to the relativism of interest groups. Any attempt to dispute such an 'oversimplification' is disciplined by allegations of transphobia, essentialism and biologism 
We reject the de-ontologization of women, the reification of hegemonic stereotypes and the radical relativism of the framework. The framework, we believe, is both contrary to and incompatible with human, women's and indeed animal and other natural rights. It is incompatible with feminist demands in areas like Pakistan or Iran where real women use secular human rights discourse, against another post postmodern feminist, Saba Mahmood. Mahmood, as mentioned, is another who draws on and develops the work of Judith Butler and Foucault, in fashioning her concept of agency in The Politics of Piety (Mahmood, 2011). She suggests that it is imperialism that has, partially, produced the liberal, secular autonomous subject of rights and effectively imposed this on those who may wish, to use Mufti's words, 'to embrace docility, submission, conservatism, patriarchy and even Islamism' (Mufti, in Zia, 2018, 39). 'Mahmood challenges what she sees as western normative assumptions effectively imposed on would be pious women in Egypt. She questions what she sees as the liberal western model of 'agency' that derives from inappropriate 'autonomous' choices that are not governed by tradition and custom. While Preciado challenges the binary man/woman, Mahmood, in parallel fashion, challenges human rights and sees these as 'western normative assumptions.

However, there are several notable activists from post -colonial Muslim majority nations who have roundly challenged these claims of Mahmood. They have celebrated the notion of universal human rights as genuinely universal and suggested that human rights are not only not western but are frequently used by activists to defend themselves against many crimes but particularly against the creeping Islamisation of their nations. Afia Zia has pointed to the many contexts in Pakistan where women activists, rather than setting out to be 'docile Muslims' have campaigned against the creeping Islamisation of Pakistan and the imposition upon them of misogynist sharia law (Zia, 2018). They have used universalist inspired human rights discourse to make their case. Assiter has also argued, in a 
forthcoming book, that the view that human rights originated in the European Enlightenment, a view that is propounded by defenders and critics of the concept alike, may itself be a form of Eurocentrism since it conveniently forgets the history of the concept in the Persian Zoroastrian tradition (Assiter, 2021).

The existence of human rights for all depends on a conception of universal humanity. The slogan 'Black Lives Matter' is important not just because all lives and the rights of all matter but because black lives and black rights have not mattered to the same degree as white lives and white rights. But it also assumes that black people exist. Similarly the existence of rights for women depends on the existence of women. So there is a link between the work of Preciado and that of Mahmood. In simple terms, Mahmood denies the existence and veracity of human rights in a Muslim majority nation context while Preciado effectively denies the existence of men and women outside the creations of colonial capitalism.

There are, we believe therefore, significant connections between our criticisms of Mahmood and the views of Preciado. If man/woman are merely fictional constructions alongside other queer multitudes then how is it possible to have women's rights not to be raped; women's rights to land; rights not to be victims of domestic violence and so on? On Preciado's analysis, these are only the 'rights' of fictional entities constructed by colonial capitalism. It would seem to follow, anyway, that pre- colonial Hindu practices that were detrimental to the interests of women, just to take one example, become acceptable because women did not exist prior to the arrival of colonial capitalism.

Post-modern feminists and some queer post-feminists suggest that the early feminists unconsciously and falsely assume this kind of abstract and formal universality in order to universalize their own perspectives. These criticisms followed on the heels of the earlier feminists' insistence that 
their male counterparts had universalized from their own partial perspective. Such criticism drew on the work of Lyotard, particularly his classic text on the subject, The Postmodern Condition (Lyotard,1979), where the author objected to the 'foundationalism' implicit in what he labelled 'grand narratives' as well as to their Enlightenment inspired and falsely optimistic faith in progress. The postmodern condition claims an identity between ontology, foundationalism, and political totalitarianism.

In this vein, some feminists argued that feminist theory must be 'explicitly historical' and 'non universalist' (Fraser and Nicholson 1990, 19-38), i.e., focused on contingent and territorial micro-agencies. Fraser and Nicholson described universalizing theories, in Lyotardian vein, as 'quasi metanarratives' (Fraser and Nicholson, 1990, 27). As another writer on the subject put it: such theories falsely universalized features of the theorists' own 'era, society, culture, class, sexual orientation, and ethnic or racial group'. In fact, to give one example, these writers argued 'there are no common areas of experience between the wife of a plantation owner in the pre-Civil War south and the female slaves her husband owns' (Bordo, $(1990,133-56))$ There are, however, a number of responses to this criticism. Universalising theories need not exclude anyone, if they are based on a developing, changing series of characteristics shared by all members of the kind.

In the world of the recent post -feminist constructivists, the presumed universalist fiction of sexual difference -that used to sustain the historical feminist struggles and multiply their claims- is now deconstructed and disseminated in multiple differences of class, races, sexual orientation, age, ethnicities, handicaps, choice of sexual object, etc. Strictly speaking, sexual difference becomes socio-linguistically undecidable with regard to many other differences, potentially infinite. 
On this new perspective, each individual becomes an undecidable assemblage of reciprocally active characteristics, actant of micropolitics geographically determined. The ontological possibility for women to be political subjects, active in state or other contexts, is abolished as will also be the chance to make any claim of equal treatment and justice outside the micropolitical premises. Instead, we would have claims locally set in communities or identity groups, if there remain any groups at all in Preciado's universe, that represent the interests of the grouping, rather than claiming justice. There is nothing wrong, to clarify, with particular claims or group claims. The problem comes when this also involves the denial of universals altogether.

On some of Preciado's assumptions there will not even be any 'identity groups' since identity is primarily a matter of self-definition and there may not even be two people sharing a particular identity category. However, even where it is possible to identify a group of people who share an identity, different problems will arise. One problematic issue would arise if the demanded interest or identity benefits some members of the group or identity and harms others, or when there are disagreements about what constitutes an identity. A seriously problematic interpretation of interest based or identity politics, therefore, is when 'community' values, like, for example, reactionary and extreme views about any group of people, are allowed to reign unchecked within certain 'identity groups'. As Pragna Patel (Patel, 2013) has pointed out, (self-appointed) community leaders often become the spokespeople and therefore the 'authentic voice' of certain communities, or of certain identity groups and this is harmful to less powerful groups within those communities. Patel speaks of the way in which the religious right in certain 'ethnic minority' communities in the UK has been granted representative status. Another problematic issue of the political position arises when a defense of the 'identity' of any one of these groupings becomes either a failure to recognize multiple forms of oppression, on the one hand, or, more controversially, circumstances 
when individuals or groups within such identified collectivities or identity groups become themselves oppressors. When, as with the work of Preciado, the 'community' includes testo junkies, 'off label characters who 'experiment' with testosterone and with their desire, who knows who might be the leaders and who the followers? In this 'community' when gender becomes a biotech-industrial artefact, in the 'pharmaco-pornographic era', testosterone may be just another molecule to control gendered subjectivity.

Communities, or identities in general, are important when they allow for the flourishing of all in the grouping. Where they work against this, then they cease to be valuable. The identity of some groups when expressed through the interest of the leaders of such groups glosses over inequalities and injustices within the collectivity. This problem is a real one. However, another problematic matter for us is that this does not concern many postmodern post-feminists, because they reject the universalist republican policies that grant recognition, the political institutions that are considered universally representative, and the sexopolitical epistemologies that dominate the production of science (Preciado, 2003, 25). Therefore, what would be necessary, according to them, is not more concrete universality, but more and more abstract particularities. However, these abstract particularities cannot offer a conception of justice even within groupings let alone across them and inside a state or a nation and this constitutes a serious limitation of the perspective, from a moral and political point of view. If all interests are to weigh equally, how are we to defend, for example, the sex trafficked person from the trafficker; the domestic violence victim from the perpetrator and so on? There would be, for example, the 'right 'to have millions of dollars and the 'right' to do what one likes with one's own body. There would be no way of adjudicating between these rights. Indeed, as noted, the concept of a right would not even exist since universals are fictional constructions. 


\section{Sed contra postmodern Post-feminisms}

The radical contingentism of post-modern and post-feminist theories then are problematic in various ways. Our orientation derives from the ontological, realist and material feminisms of sexual difference, and we renounce the concealed phallogocentrism of the above trend, which we suggest serves to defend the patriarchal and capitalist status quo. It does this, partly, as we have suggested above, through failing to consider questions of equality or justice and instead focusing, in a radically sceptical manner, on 'letting a thousand flowers bloom'. Some of these flowers, though, will be exploiting others. But is also constitutes, ironically a conservative form of neo-liberalism, since it erases, as fictional constructions, the very categories necessary to sustain justice and equality. It erases the categories in equalities legislation that sustain liberal democracies, in favour of the fictional constructions of capitalist neoliberalism. Although it purports to be radical, it renounces the resources necessary for radicalism and treats all practices, all forms of 'abjection' as on a par. It therefore fails to provide the tools for excluding far right practices - such as medical experiments on children - since anything 'abject' is allowable. We submit, and we have defended this elsewhere, that it is possible to defend a form of universalizing, materialist feminism without being committed either to determinism, essentialism or foundationalism - the various positions denounced by Butler. Suffice it to say for now that our position derives, rather, from a Schellingian and Hegelian ${ }^{8}$ inspired form of 'universal becoming' which is also partially Darwinian in inspiration.

Other feminists than us have denounced the disguised misogyny and femino-phobia (Braidotti, 2002, 29, 50) of removing women as ontological subjects and deconstructing their identity into socio-linguistic variables of class, ethnicity, race, culture, religion, choice of sexual object, etc, 
Women's sex, according to the postmodernists and the post feminists, must be eliminated along with the hetero-normative construction to which it has been assimilated. But this has the main effect of reinforcing sexist stereotypes and disabling the change of old sociocultural signifiers associated to female identity by the active and creative transformation of women. That is why authors like Rosi Bradotti or Elizabeth Grosz consider that the notion of a queer multitude is 'a reactive category that sees itself in opposition to a straight norm' (Grosz, 1995, 219), so that it reifies or essentializes the norms in order to transgress them.

Another deceit of the de/constructivist theory is the (a)sexual neutrality of the speaking subjects: a sort of tabula rasa in which it is possible to inscribe all libidos, desires, genders, sexes, sexualities, materialities, bodies, etc. As feminist thinkers well know, where there is supposed to be neutrality, there is likely to be a disguised masculinization. In fact, some countersexual queer groups reproduce the cult of male supremacy and the subordination of female positions within homo- or trans-normative performances (Jeffreys, 2003). Homosexuality in itself does not overcome patriarchy. To the contrary, there is a homosexual patriarchy as well as there is a hetero-sexual one, both based -as Sade teaches- on the domination of women in the frame of a homo-normative system which is negotiated from a man -to man -women exchange.

The reduction of woman to a heteronormative social construction takes for granted that patriarchy constitutes a heteronormative system, and neglects that it is actually also a homonormative regime settled from man to man (Raymond, 2001, 10-11). Patriarchal homo-reality expresses the subordination of women to male exchanges. Besides, identifying woman with heteronormativity, post-feminism reduces sexual libido to discursive practices and cultural representations, equates sexuality with genitality, oversimplifies vital drives, passes over material and unconscious energies, and turns sexed bodies into mere devices of power. For Preciado, 'we 
don't have a body that we come later to reflect ourselves upon. We make ourselves a body, we earn our own body' (Preciado, 2018, 14).

As Slavoj Žižek has pointed out, the question is to what extent the infinite counter-sexual variations that have come to liberate sexuality from the binary oppression actually 'end up in the abandoning of the very sphere of sexuality-the liberation of sexuality has to ends up in the liberation (of humanity) from sexuality' (Žižek, 2017, 134). As a matter of fact, countersexuality has nothing to do with the vital or living drives that Freud has described, and one is bound to wonder, again with Žižek, how many other features usually identified with sexuality such as art, creativity, consciousness, we will also abandon (Žižek, 2017, 134). Neutral subjects and transsexual constructions speak to us about a trans-humanity no less fictional than postmodernity.

Ontologically speaking, the de-ontologization of women entails a 'theoretical violence' (Malabou, 2011, 99) that supports the practical violence exercised historically against them. Such a conceptual violence is based on a dualistic scheme according to which there are just two opposite alternatives: either the classic metaphysics of the substance, formalized by the logic of the representational and abstract understanding, or the postmetaphysical de/constructivism, articulated by discursive performances signifying in the emptiness of the real. Both coincide in the exclusive and irreconcilable opposition between the immediately given and the historically constructed, the fixed identity and the dissolvent difference, the natural and the cultural, the subjective and objective, the necessary universal and the contingent particular, as if the one cannot be dialectical and the other cannot be dynamic. This false alternative forces us to a fake choice.

Post-modern post-feminism chooses a fictional nominalism that ends in relativism and skepticism, and, paradoxically, promotes the most 
reactionary and conservative positions. In their desire not to fall foul of the supposed Enlightenment conceit - as a foundationalist project - wellmeaning non-universalists may have inadvertently allowed pernicious and right-wing values to take root.

As an analogous example, while it is the case that racism in general or 'racism' against Muslims or other religious groupings, or discrimination against Christians (expressed in many parts of the Middle East and elsewhere today) are each unjust and oppressive practices, it is also true that fundamentalist forms of religion that may be practiced by those Christians or those Muslims are also oppressive and unjust. It is only a belief that both racism and sexism are unjust, that allows and indeed requires all of us to condemn both. In other words, in the present context, a universalizing voice is important in order to challenge oppressive forms of self-definition, exploitative forms of sexuality and indeed even to be able to make the point that certain forms of sexuality are oppressive and discriminatory.

There is, then, a universalist perspective outside the dualist alternative between a totalitarian foundationalism, based on the logic of abstract identity, and a multicultural relativism, based on the logic of abstract multitudes. Our alternative proposal is a concrete and singular universality -or universal individual- capable of mediating the rational demands of justice in each particular and contingent case, the unum into the alia. We propose an immanent, dialectical and dynamic universality instead of a transcendent, substantial and immutable one. We agree that a representational universality abstracted from the particular may involve an inappropriate denial of difference or 'alterity' amongst subjects differences arising from situation, context, class, race, emotion and other aspects of individuality - and may leave out important characteristics that differentiate humans from one another. However, we uphold a concrete universality mediated by material, emotional and cultural determinations. 
In the same vein, it is important to note that it is possible to believe in a universal theory without upholding a foundationalist epistemology, i.e., without supporting the transcendence of an eternal and immutable substance that regulates the end of all movement. On the contrary, we endorse a kind of universality which means immanent action - instead of objective representation - and belongs to an emancipatory reason that provides a basis for critiquing exclusionary and oppressive norms.

Therefore, it is possible to uphold a universalist outlook about women without falsely generalizing from one's own perspective. As Margaret Whitford once put it (Whitford, 1991, 5), feminist membership is like Merleau-Ponty's heap of sand: each grain individually is minute and slightly different from all the others, but the whole sandbank may block a river.

Woman is multiple. There are many classes of women, many races, sexual orientations, ages, ethnicities etc. Perhaps each one of these has come into being as the result of a number of processes or as the expression of a number of powers. Some of these powers are biological; some are social; some psychic or spiritual. All these differences do not deny but confirm her universality.

It is a universalizing perspective that recognizes our collective shared humanity and the needs and rights that stem from this. Such a universalizing perspective allows us to recognize crimes against humanity in general and women in particular. It sees universal humanity as lying in a continuum with the natural and the non-human world. The fictional nominalism of postmodern post-feminism reinforces what should be eliminated. And the same applies for gender stereotypes, extrinsically reified as social norms instead of internally transformed by women's emancipation. 
There is one last objection that must be considered and this resides in post modern and post --feminist abolition of matter as active and creative energy. In this regard, post-feminism seems to consummate what Luciana Parisi calls 'the most classical of patriarchal dreams: independence from matter' (Parisi, 2004, 2). Precisely the reduction of materiality to sociolinguistic materializations is one of the issues most criticized by the new material and realist feminisms (Alaimo, Hekman, 2008). According to them, postmodern socio-linguisticisms reproduce the phallogocentric vice of turning matter into the mere passive recipient of active per-forms. To quote Shaviro once more: 'Where did we ever get the idea that nature as opposed to culture - is ahistorical and timeless?' (Shaviro, 1997).

In this instance, the classical patriarchal dream merges with the omnipotence fantasy of queer multitudes, those fantasies of 'escaping from the body' (Braidotti, 2002, 223) in order to become the technoconstruction one wants. This will-to-disembodiment has the support of a pharmacopornographic bio-capitalism eager to produce new embodiments. The advanced commodities of the free market are now trans-species, minds, bodies, desires, affects, femininities, masculinities (Preciado, 2013, 51). The transgender trans-humanity of the future is coming between fiction and reality, life and death, male and female.

And while the era of total disembodiment is nigh, we have the bodies of women and children in off-shore production plants (Braidotti, 2006, 30), the bodies of sexual and reproductive exploitation, the ablated bodies of Muslim women, the amputated and intoxicated bodies of FTM and MTF. Whereas the utopia of neutral cyborgs and the fictions of transgender techno-sexualities continue in undecidable expansion, the only objection to postmodern post-feminism is the actual matter of living beings. These living beings are the beings who protest against fundamentalist regimes and fundamentalist politics in India, Pakistan, Iran, Brazil, USA and in many more nations and places in the world. These living beings indeed include 
trans men and women who are also real beings and who themselves protest about some of the above fundamentalist practices.

The fictional world of Preciado, indeed, may itself be a product of advanced capitalism, that provides opportunities for some to practice a sophisticated form of desire. It leaves others without the framework really existent human beings - to protest about their poverty. Some who experience the extreme control of their thoughts, desires and behaviour by the forces of fundamentalism in nations governed by sharia law, need to come together as women, as trans people, as anti-racists or as any other really oppressed person, to fight for their rights. They don't need 'dildoisation'.

This paper has challenged a number of aspects of the new post -feminist fictional universe of Preciado as politically dangerous in a number of different respects. We have demonstrated that there is a move from a fictional reality and a recognition and appreciation of abject bodies, to a celebration of destructive and dangerous forms of sexuality. We have expressed worries about the very idea of a fictional reality in so far as it leaves no scope for determining which practices are dangerous and which are harmless and/or wrongly unrecognized. We have suggested, therefore, that Preciado's theory may be conservative and neo-liberal in its consequences. We have challenged, moreover, the idea that the binary of man/woman is a product of western colonial capitalism since this itself creates a further unwelcome binary - that between human and the natural world and it also has the odd consequence that women and men did not exist prior colonial capitalism. We have, finally, suggested a new form of universalist essentialism - a dynamic ${ }^{9}$ Schellingian/Hegelian concrete universality partially biologically formed. 
Alison Assiter is Professor of Feminist Theory in Philosophy at the University of the West of England, Bristol and a feminist, a writer and political activist. She volunteers for Haringey Migrant Support centre and is an active editorial board member of Feminist Dissent. She has written a number of books and articles and has specialised on the work of Kierkegaard. Her forthcoming book A New Theory of Human Rights: Zoroastrianism and New Materialism, will be out in 2021, with Rowman and Littlefield.

María J. Binetti holds a PhD in Philosophy from the University of Navarra (Spain), and a MA in Women and Gender Studies from the University of Luján (Argentina). She is a researcher at the National Council for Scientific and Technical Researching (Argentina), and postgraduate professor at several national universities. Her areas of interest are contemporary continental philosophy, existentialism, German Idealism, and feminist philosophy. Currently, her research is focused on a feminist philosophy of sexual difference conceptualized within the framework of the new speculative realism. Among her publications are Mater/realismo. Aportes para una filosofía feminista de la diferencia sexual (Prometeo, Buenos Aires, In Press), El idealismo de Kierkegaard (Universidad Iberoamericana, México 2015), El poder de la libertad. Introducción a Kierkegaard (Ciafic Ediciones, Buenos Aires 2006), as well as several articles in international journals. She is engaged in political activity on the issue of sex based rights.

\section{References}

Alaimo, Stacy and Hekman, Susan (eds.) (2008) Material Feminisms, Bloomington: Indiana University Press.

Assiter, A. (1996) Enlightened Women, Modernist Feminism in a Post Modern Age, London: Routledge 
---(2021) A New Theory of Human Rights: New Materialism and Zoroastrianism, London: Rowman and Littlefield.

Bakari-Yusuf, Bibi (2003) “'Yoruba's don't do gender": a critical review of Oyeronke yewumi's The Invention of Women: Making an African Sense of Western Gender Discourses', https://codesria.org/IMG/pdf/BAKERE_YUSUF.

Barad, Karen (2003) Post Humanist Performativity: Towards an Understanding of how Matter came to matter, Signs, Journal of Women in Culture and Society, Vol. 28, No.3.

Braidotti, Rosi (2013) The Post human, Cambridge: Polity Press.

---(2006) Transpositions: On Nomadic Ethics, Cambridge: Polity Press ---(2002) Metamorphoses: Towards a Materialist Theory of Becoming, Cambridge: Polity Press.

---(1994) Nomadic Subjects: Embodiment and Sexual Difference in Contemporary Feminist Theory, New York: Columbia University Press.

Butler, Judith (2004) Undoing Gender, New York: Routledge.

---(1993) Bodies that Matter. On the discursive Limits of 'Sex', New York: Routledge.

---(1990), Gender Trouble: Feminism and the Subversion of Identity, New York: Routledge.

Brayboy. D. (2017) Two Spirits, One Heart, Five Genders, Indian Country Today: Arizona State University.

Connolly, Kate \& Kassam, Ashifa \& Willsher, Kim \& Carroll, Rory (2020) "We are losers in this crisis': Research finds lockdowns reinforcing gender inequality', The Guardian, May. 
De Lauretis, Teresa (1987), Technologies of Gender: Essays on Theory, Film, and Fiction, Bloomington \& Indianapolis: Indiana University Press.

De Vries, Kylan Mattias (2009) 'Berdache (Two-Spirit)', in O'Brien, Jodi (ed.). Encyclopedia of gender and society, Los Angeles: Sage

Estrada, Gabriel (2011) 'Two Spirits, Nádleeh, and LGBTQ2 Navajo Gaze' American Indian Culture and Research Journal, 35 (4), 167-190.

Foucault, Michel (2015), Language, Madness, and Desire. On Literature, Minneapolis: University of Minnesota.

---(1976), Histoire de la sexualité 1, La volonté de savoir, Paris: Éditions Gallimard.

Gatens, Moira. (1996) Imaginary Bodies: Ethics, Power and Corporeality, London: Routledge.

Grosz, Elizabeth (1995) Space Time, and Perversion. Essays on the Politics of Bodies, New York \& London: Routledge.

Grosz, Elizabeth and Probyn, Elspeth (eds.) (1995) Sexy Bodies, The Strange Carnalities of Feminism, New York: Routledge.

Halberstam, Judith (2005) Female Masculinity, Durham: Duke University Press.

Hague, G. (2021, forthcoming May) History and Memories of the Domestic Violence Movement: We've come further than you think, Bristol: The Policy Press

Jeffreys, Sheila (2003) Unpacking Queer Politics: A Lesbian Feminist Perspective, London: Polity Press. 
Malabou, Catherine (2011) Changing Difference: The Feminine and the Question of Philosophy, Cambridge: Polity Press.

Mahmood, Saba (2011) The Politics of Piety: the Islamic Revival and the Feminine Subject, Princeton: Princeton University Press.

Nussbaum, Martha (1999) The Professor of Parody, the Hip Defeatism of Judith Butler, The New Republic, February, 22.

Oyewumi, Oyeronke (1997) The Invention of Women: Making an African Sense of Western Gender Discourse, Minneapolis: University of Minnesota Press.

Parisi, Luciana (2004) Abstract Sex, Philosophy, Biotechnology and the Mutations of Desire, London \& New York: Continuum.

Preciado, Beatriz-Paul (2003) 'Multitudes Queer: note pour une politique des anormaux', en Multitudes, 17-25.

---(2013) Testo Junkie: Sex, Drugs, and Biopolitics in the Pharmacopornographic Era, New York: The Feminist Press.

---(2018) Counter-sexual Manifesto, Translated by Kevin Gerry Dunn, Columbia University Press: New York.

Raymond, Jenice G. (2001) A Passion for Friends: Toward a Philosophy of Female Affection, Melbourne: Spinifex.

Romans, et. al. (2000) The Perpetrators of Domestic Violence, Med J. Aust, 6, 173 (9), 484-8. 
Rubin, Gayle (1975) 'The Traffic in Women. Notes on the Political Economy of Sex', en Rayna R. Reiter (ed.), Toward an Anthropology of Women, New York \& London, Monthly Review Press, 157-210.

Shaviro, Steve (1997) Doom Patrols: A Theoretical Fiction about Postmodernism, Serpents Tail High Risk Books.

Stringfellow, Isobel (2020) Intersectionality: Does Gender Equality Lie in the Analysis of Interlocking Oppressive Forces, Dissertation for level 3, UWE Bristol.

Tucker, R. (2013) 'Pharmaco-pornography: An Interview with Beatriz Preciado', The Paris Review, 4 December.

Walby, S. and Allen, J. (2004) Domestic Violence, Sexual Assault and Stalking, Findings from the British Crime Survey, Home Office Research Study, 276, London: Home Office.

Walby, S and Towers, J (2017) 'Measuring Violence to end Violence: Mainstreaming Gender', Journal of Gender Based Violence, Vol.1.

Whitford, Margaret (1991) Luce Irigaray: Philosophy in the Feminine, London: Routledge.

Zia, Afia (2019) Faith and Feminism in Pakistan: Religious Agency or Secular Autonomy, Brighton: Sussex Academic Press.

Žižek, Slavoj (2017) Incontinence of the Void, Economico-Philosophical Spandrels, Cambridge \& London: The MIT Press. 


\section{To cite this article:}

Assiter, A and Binetti, M. J. (2020). A postmodern Post-feminism without Women, Feminist Dissent (5), 204-241. Retrieved from:

https://doi.org/10.31273/fd.n5.2020.765

\section{Notes}

${ }^{1}$ We are very grateful for the incisive comments on an earlier version of the paper from Gita Sahgal, Rebecca Durand, Nira Yuval-Davis and Sukhwant Dhaliwal.

${ }^{2}$ See Hacking the Binary: JCU Welcomes Philosopher Paul B. Preciado, October 31st 2019

${ }^{3}$ These claims about postmodernism will seem controversial to some. We have argued the case for this in Assiter A. Enlightened Women: Modernist Feminism in a Post Modern Age, Routledge, 1996.

${ }^{4}$ This was drawn to our attention by my (Assiter's) student Isobel Stringfellow, in her dissertation, Intersectionality: Does Gender Equality Lie in their Analysis of Interlocking Oppressive Forces? Dissertation level 3, August 2020.

${ }^{5}$ The film, Two Spirits, directed by Lydia Nibley documented this story.

${ }^{6} \mathrm{I}$ am grateful to Rebecca Durand for drawing my attention to this body of work.

${ }^{7} \mathrm{I}$ am indebted to the domestic violence expert Gill Hague for this information. See also https://www.womensaid.org.uk/information-support/what-isdomestic-abuse/domestic-abuse-is-a-gendered-crime/

${ }^{8}$ Our inspirations are the work of Schelling and Hegel as well as some contemporary biologists who emphasise a dynamic view of the biological. See, for example Andreas Weber and Francisco J. Varela, Life after Kant: Natural Purposes and the Autopoietic Foundations of Biological Individuality, Phenomenology and the Cognitive Sciences 1:97-125, 2002, 97. 